\title{
Germination and seedling growth of Brassica juncea and Medicago sativa under exposure to microcystins- contaminated water from Dau Tieng reservoir
}

- Dao Thanh Son

University of Technology, VNU-HCM

- Le Thai Hang University of Science, VNU-HCM

- Pham Thanh Luu

University of Tsukuba, Japan

- Do Hong Lan Chi

Vietnam National University - Hochiminh City

(Manuscript received on $11^{\text {st }}$ November 2014, accepted on $26^{\text {th }}$ December 2014)

\section{ABSTRACT}

Occurrence of toxic cyanobacteria and their toxins has been a root of many consequently serious problems to aquatic plants, animals, and human in the world. However, the toxicity of cyanobacterial toxins from Vietnam waters to the germination and growth of plants has not studied yet. In this study, we investigated the effects of microcystins (MC) (at the concentrations of 20 and $200 \mu g M C L-1)$ from field water and crude extract of cyanobacterial scum (mainly Microcystis spp.) from the Dau Tieng Reservoir, on the germination and seedling of Brassica juncea and Medicago sativa during 7 days. The results showed that MC inhibited the germination of the exposed seeds from 10 - 35\% compared to the control. The fresh weight of exposed $B$. juncea and $M$. sativa compared to the control was from $44-89 \%$ and from 55 $90 \%$, respectively. Root length of the plants reduced from 12 - 73\% for $B$. juncea and from $17-54 \%$ for $M$. sativa during toxin exposures. Similarly, the decrease of the shoot length, compared to the control, was from $20-80 \%$ for B. juncea and $13-52 \%$ for $M$. sativa. Therefore, the use of water contaminated with MC for irrigation may negatively influence on the quality and yield of agricultural crops. It could be inferred that there should be an uptake of MC by the exposed seeds and th toxin might be transferred to the next consumers via the food chain.

Key words: Brassica juncea, Medicago sativa, growth, microcystins, seedlings. 


\section{INTRODUCTION}

Cyanobacterial blooms have been increasing in freshwater sytems during the last decades all over the world. These blooms and their associated toxins (e.g. microcystins, cylindrospermopsin, anatoxin-a) caused diversely adverse effects on plants, animals and human being [15]. Numerous investigations have showed that cyanobacterial toxins (e.g. MC) could also accumulate in plants and induce severe effects on plants at different aspects such as enzyme activities, photosynthesis, seedling and growth. Studies on the bioaccumulation of MC in different parts (e.g. leaves, rhizomes, stems, bark protein) of plants such as aquatic macrophytes, broccoli, mustard, have been conducted and reported $[6,7,11,12]$. In addition, toxic Microcystis aeruginosa and MC were observed and found on salad letture after the plant was sprayed with water containing the toxic cyanobacterium [2].

Cyanobacterial extracts containing toxins inhibited the seedling and growth of macrophytes [9]. MC caused the growth inhibition of rape, rice and mustard [1,7]. Exposure to MC induced a decrease in germination, roof and leaf length of spinach [13]. Besides, MC-LR, MC-RR and anatoxin-a also reduced the chlorophyll and carotenoid concentrations in plant $[1,5,19]$ and caused malformation on mustard [7]. The photosynthesis of macrophytes was inhibited by cyanobacterial crude extracts or pure toxins (e.g. MC, microcin SF608 and anatoxin-a) $[14,20]$.

MC caused oxidative stress response in duck week seedlings including lipid peroxidation, change of tocopherol concentrations and profile, and elevation of glutathione enzyme activities [16]. The activities of antioxidant and biotransformation enzymes (superoxide dismutase, peroxidase, catalase, glutathione Stransferase, glutathione peroxidase) in plants were significantly changed by cyanobacterial toxins at the concentrations from $0.5-10 \mu \mathrm{g} \mathrm{L}^{-1}$ $[5,16,19]$. The glutathione level was reduced and superoxide dismutase and catalase activities were evoked in cells of Arabidopsis thaliana and Nicotiana tabucum exposed to MC [17, 18].

Toxic cyanobacteria and their toxins are wildly distributed in freshwater bodies in Vietnam. In nature, the MC concentrations in surface water were up to $1.5 \mu \mathrm{g} \mathrm{L}^{-1}$ in Nui Coc Reservoir, Thai Nguyen Province, more than 76 $\mu \mathrm{g} \mathrm{L}^{-1}$ from freshwater localities in Hue City, and from $127-161.5 \mu \mathrm{g} \mathrm{L}^{-1}$ in from Tri An and Dau Tieng Reservoir in Southern Vietnam. Besides, MC concentrations from the isolated Microcystis strains in Vietnam could reach $4120 \mu \mathrm{g}$ per gram dried weight [3]. In the field, plants could be irrigated with water contaminated with toxic cyanobacteria and their toxins. Hence plants could accumulate and be affected by cyanotoxins. To our knowledge, toxicity of cyanobacterial toxins from Vietnam to plants is unknown. Therefore, in this study we investigated the effects of MC contained in cyanobacterial extract and in water from Dau Tieng Reservoir on the germination rate and seedling growth of Brassica juncea and Medicago sativa.

\section{MATERIALS AND METHODS}

\section{Materials}

The seeds of Brassica juncea and Medicago sativa were purchased from a super market in Hochiminh City. Cyanobacterial scum (mainly Microcystis spp) collected in July 2011 and (raw) field water sample during cyanobacterial scum (mainly Anabaena flos-aquae) from Dau Tieng Reservoir collected in September 2012 were used for experiments.

Cyanobacterial crude extract preparation and microcystins analysis

Trang 34 
Field water sample (collected in September 2012) was filled via plankton net $(25 \mu \mathrm{m}$ mesh size) and stored at $-80^{\circ} \mathrm{C}$ prior to experiments. Crude extract from cyanobacterial scum was prepared according to Pietsch et al. [14] with minor modification. Briefly, dried biomass of scum and isolates on GF/C filters was homogenized, suspended into reversed osmosis water, sonicated, frozen at $-80^{\circ} \mathrm{C}$ over night and thawed at room temperature. The freeze/thaw cycle was repeated five times. After the last thawing cycle, samples were centrifuged at 4500 $\mathrm{rpm}, 4^{\circ} \mathrm{C}$ for $15 \mathrm{~min}$. Supernatants were collected and kept at $-80^{\circ} \mathrm{C}$ prior to experiments.

For MC analysis, sub-samples of field water and cyanobacterial crude extract were centrifuged at $14000 \mathrm{rpm}, 4^{\circ} \mathrm{C}$ for $15 \mathrm{~min}$. Supernatants were collected for MC analysis by high performance liquid chromatography (HPLC). HPLC (Shimadzu, Japan) is equipped with a silica based reverse phase $\mathrm{C}_{18}$ column (Waters SunFire ${ }^{\mathrm{TM}}$, Ireland), maintained at $40^{\circ} \mathrm{C}$. A $0.05 \mathrm{M}$ phosphate buffer $(\mathrm{pH} 2.5)$ in methanol $(50 / 50, \mathrm{v} / \mathrm{v})$, at a flow rate of $0.58 \mathrm{~mL} \mathrm{~min}^{-1}$, was used as mobile phase. MC congeners were detected by the UV detection at $238 \mathrm{~nm}$ with a photodiode UV-visible array detector. The MC variants $\mathrm{MC}-\mathrm{RR},-\mathrm{YR}$ and $-\mathrm{LR}$ purchased from Wako chemicals company (Osaka, Japan) were used as standards.

\section{Exposures of Brassica juncea and Medicago sativa to microcystins}

For experiment, 40 seeds (3 replicates) of each plant species (Brassica juncea and Medicago sativa) were used for MC exposures. The seeds were placed on tissues paper in petri dishes and daily watered with $5 \mathrm{~mL}$ of field water (containing 20 (DT20) or 200 (DT200) $\mu \mathrm{g} \mathrm{MC} \mathrm{L-}$ ${ }^{1}$ ) or cyanobacterial crude extract (containing 20 (Sc20) or 200 (Sc200) $\mu \mathrm{g} \mathrm{MC} \mathrm{L}^{-1}$ ). The $\mathrm{MC}$ concentrations used for exposure were based on the maximal dissolved toxin concentration

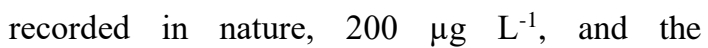
concentration 10 times lower than the maximal, also the guide line value of MC for human contact [15].

Another treatment was also conducted as control in which the seeds were watered with distilled water only. Experiments were run at $25 \pm 1^{\circ} \mathrm{C}$, in dark during the first 2 days. From the third day to the end of incubation ( 7 days), the seedlings were placed under light intensity of around 1500 Lux and light: dark cycle of $12 \mathrm{~h}$ : $12 \mathrm{~h}$.

The parameters observed were fresh weight (FW), shoot length and root length of the seedlings at 2, 4 and 7 days of incubation. The FW was determined by a balance (Sartorius BP 201S, Germany) and the length was measured with a ruler, exactly to $1 \mathrm{~mm}$.

\section{Statistical analysis}

Sigmaplot, version 12.0 was used for data treatment. One-way Analysis of Variance (ANOVA) and Tukey test Post Hoc were applied for calculation of statistically significant difference of the FW, shoot and root length of seedlings after the data were checked for variance homogeneity (Levenes) and normality (Shapirow-Wilk's test).

\section{RESULTS AND DISCUSSION}

The HPLC analysis showed that the cyanobacterial crude extract and field water contained MC-RR and MC-LR (Fig. 1) at the total concentrations of $650 \mu \mathrm{g} \mathrm{g}^{-1}$ dry weight and $1000 \mu \mathrm{g} \mathrm{L}^{-1}$, respectively. The MC concentration from cyanobacterial scum sample in this study is in range with previous records from the field in Vietnam [3]. However, the MC concentration in water sample from Dau Tieng Reservoir was extremely higher than those ever reported from Vietnamese waters. 

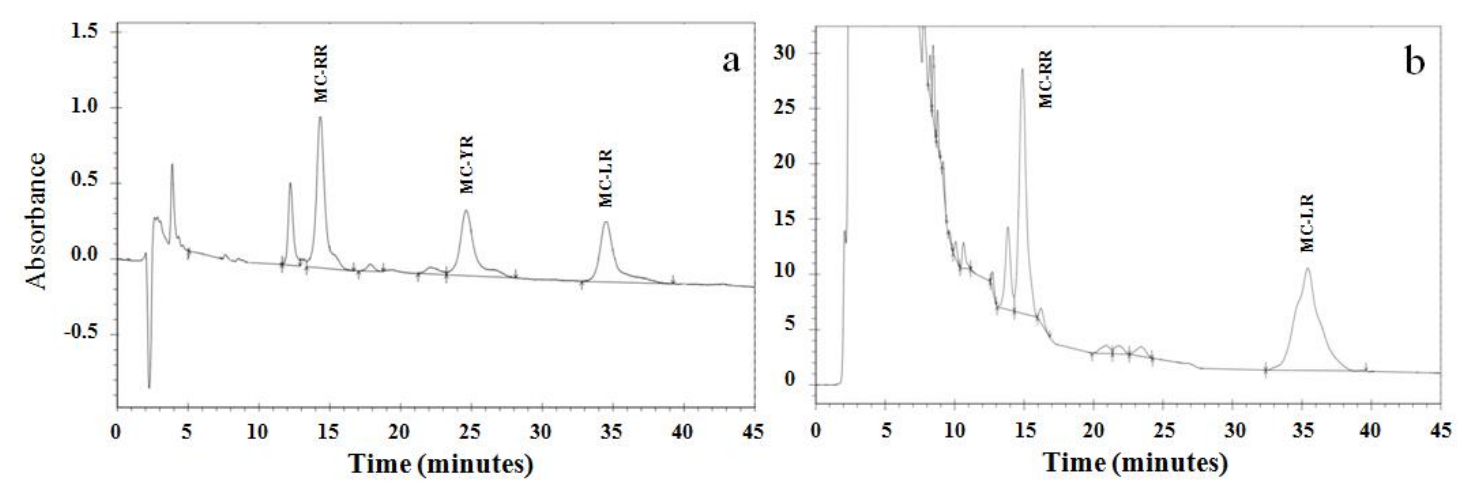

Figure 1. HPLC chromatography of microcystin standards (a) and field water sample (b)

Table 1. Germination rate (\%) of Brassica juncea and Medicago sativa after 7 days of incubation

\begin{tabular}{cccccc}
\hline Seeds of plants & \multicolumn{5}{c}{ Exposures } \\
\cline { 2 - 5 } & Control & DT20 & DT200 & Sc20 & Sc200 \\
\hline Brassica juncea & $100 \%$ & $90 \%$ & $90 \%$ & $100 \%$ & $65 \%$ \\
Medicago sativa & $100 \%$ & $87.5 \%$ & $82.5 \%$ & $90 \%$ & $90 \%$ \\
\hline
\end{tabular}

The high MC concentrations during Microcystis spp and Anabaena flos-aquae scum from Dau Tieng Reservoir possessed a serious risk to local residents who daily use the water from the reservoir for domestic activities. Additionally, this is the first report on the MC producing cyanobacterium A. flos-aquae from Vietnam.

During exposure period, all seeds in control treatment germinated. However, exposures to MC from field water or cyanobacterial crude extract resulted in the reduction of the seed germination from $10-35 \%$ (table 1). This adverse impact could be related to that MC alters the activities of important enzymes in plants (e.g. protein phosphatases 1 and $2 \mathrm{~A}$ ) [8], consequently interferes the metabolisms in cells then inhibits the germination processes of the seeds.

It is interesting that the germination of $B$. juncea seeds was only strongly inhibited in exposure to $200 \mu \mathrm{g} \mathrm{MC} \mathrm{L}{ }^{-1}$ from crude extract whilst that of $M$. sativa seeds was significantly repressed by MC from field water. Properly, different species (B. juncea and $M$. sativa) would have different response to MC which needs further investigation.

After 2, 4 and 7 days of incubation, the FW of both plant species, B. juncea and M. sativa, from exposures to either field water or cyanobacterial crude extract was significantly decreased as compared to control (ANOVA followed by Tukey test, $\mathrm{p}<0.05$; Fig. 2a-f). Besides, high MC concentration (200 $\mu \mathrm{g} \mathrm{L}^{-1}$ from DT200 and Sc200) had stronger impact than low toxin one (20 $\mu \mathrm{g} \mathrm{L}^{-1}$ from DT20 and Sc20). Consequenlty, FW of exposed plants from 200 $\mu \mathrm{g} \mathrm{MC} \mathrm{L}^{-1}$ treatment was lower than that of 20 $\mu \mathrm{g} \mathrm{MC} \mathrm{L^{-1 }}$ treatment.

\section{Trang 36}



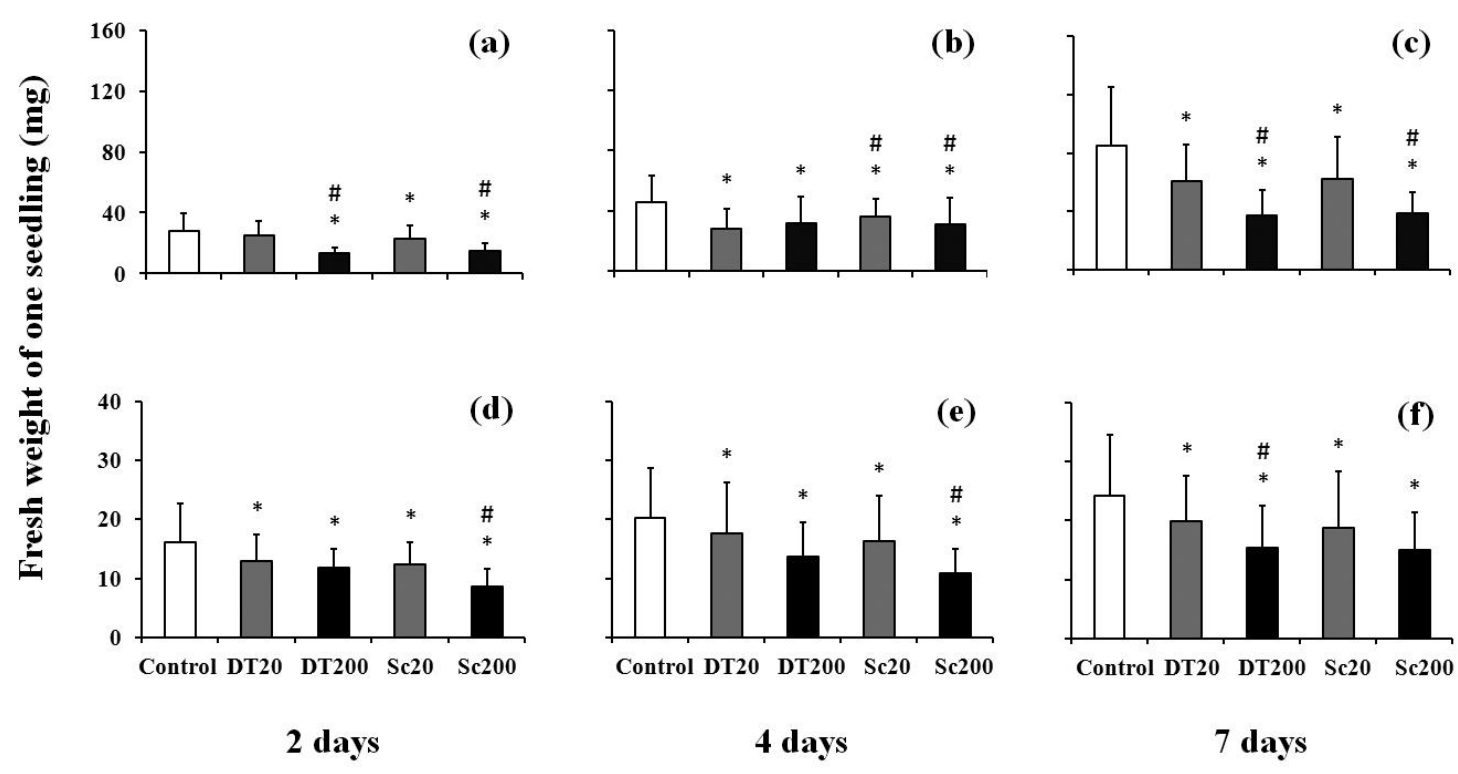

(c)
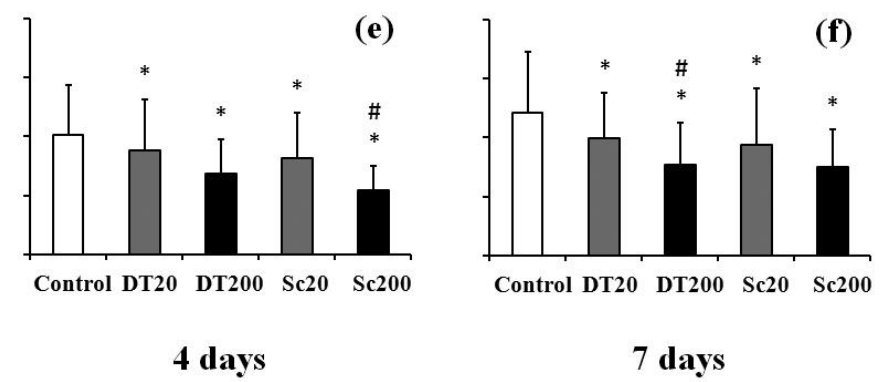

7 days

Exposures

Figure 2. Fresh weight $(\mathrm{mg})$ of the seedlings (mean value $\pm \mathrm{SD}$ of $\mathrm{n}=40$ ) during incubation of Brassica juncea (a, $\mathrm{b}, \mathrm{c})$ and Medicago sativa (d, e, f). The asterisk indicates significant difference between control and toxin exposures ( $\mathrm{p}<0.05)$ and the \# symbol indicates the significant difference between DT 20 and DT200 or Sc20 and Sc200 (p < $0.05)$ by ANOVA followed by Tukey test.
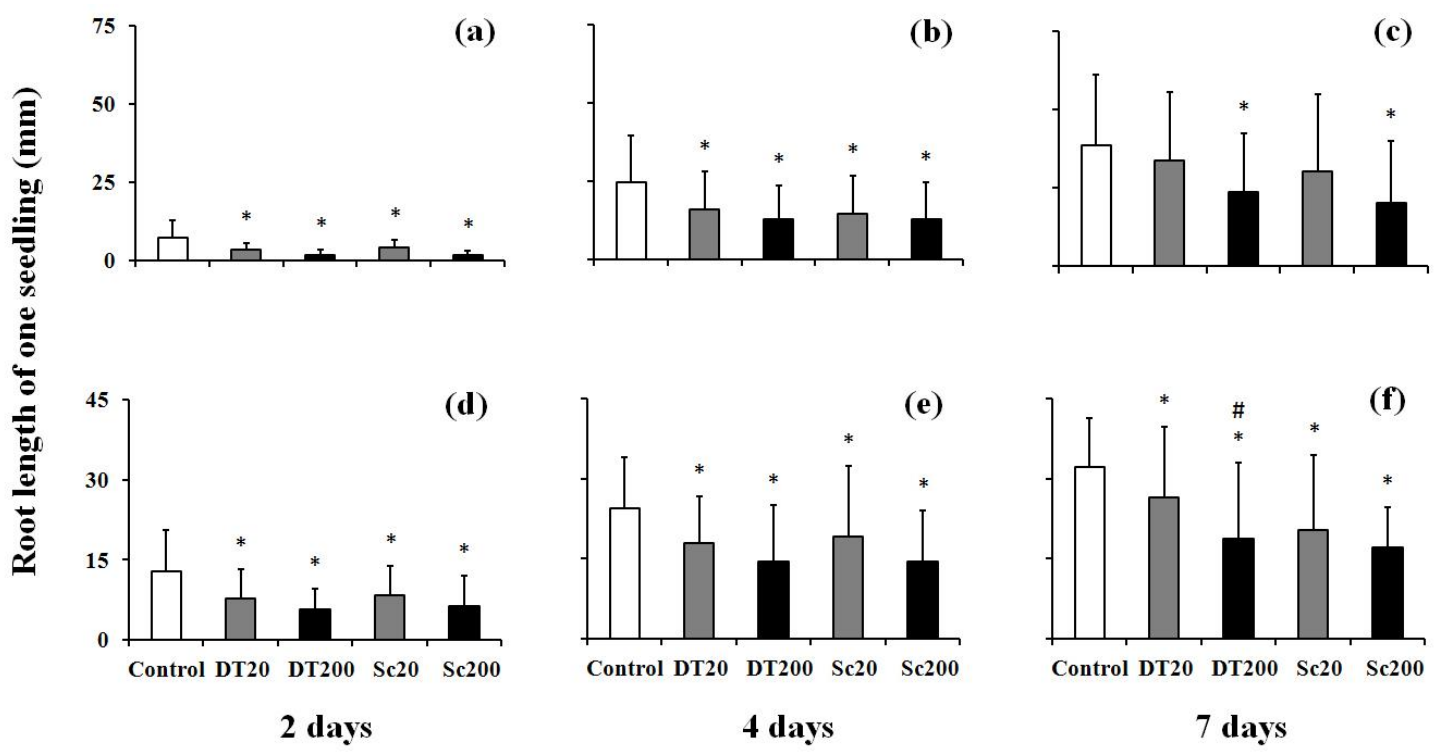

Exposures

Figure 3. Root length $(\mathrm{mm})$ of the seedlings (mean value $\pm \mathrm{SD}$ of $\mathrm{n}=40$ ) during incubation of Brassica juncea (a, $\mathrm{b}, \mathrm{c})$ and Medicago sativa (d, e, f). Abbreviations as in figure 2. 


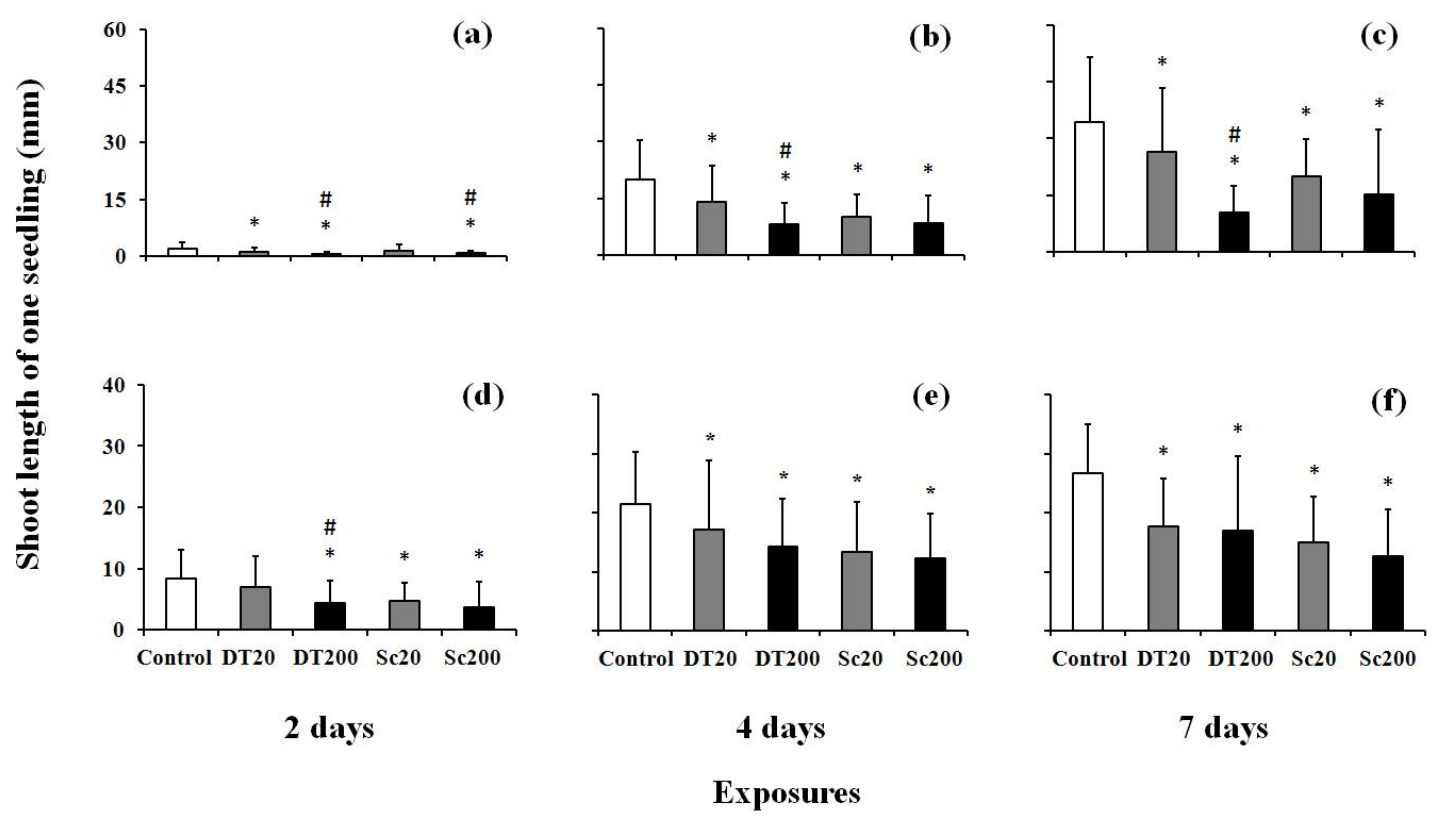

Figure 4. Shoot length $(\mathrm{mm})$ of the seedlings (mean value $\pm \mathrm{SD}$ of $\mathrm{n}=40$ ) during incubation of Brassica juncea (a, $\mathrm{b}, \mathrm{c})$ and Medicago sativa (d, e, f). Abbreviations as in figure 2.

Previous investigations showed that FW of potato and germination of spinach were inhibited by cyanobacterial crude extract $[1,2]$ which was supported by the significantly $\mathrm{FW}$ reduction of exposed B. juncea and $M$. sativa compared to the control from our study. The FW of seedlings of plants during the first days of germination should be involved in the amount of water they took up. MC induced oxidative stress response [16] and inhibited ATPase [10] which would lead to the alteration of the metabolism processes in seedlings during germination consequently water uptake and seedlings of the exposed seeds and plants. In detail, the FW of B. sativa was 28,46 and $85 \mathrm{mg}$ after 2, 4 and 7days of incubation, respectively. However, the $\mathrm{FW}$ of exposed $B$. sativa only gained from $44-89 \%, 78 \%$ and $73 \%$ of the control FW. Similarly, the FW of $M$. sativa from the exposures was from $55-90 \%$ compared to the control. Therefore, it could be inferred that $\mathrm{MC}$ reduced the water uptake capacity of seeds hence inhibited FW increase of the seedlings of B. juncea and M. sativa in the present investigation. Besides, the detoxificaion of MC in plant cells to balance the activities of biotransformation and antioxidant enzyme [5, 13, 20] would lead to the decrease of the energy or material for growth of the seedlings which partly involved in the reduction of FW of seedlings in the MC exposures compared to the control.

The root and shoot length of $B$. juncea and $M$. sativa in control treatment always significantly longer than that in $\mathrm{MC}$ exposures at 2, 4 and 7 days of incubation (ANOVA followed by Tukey test, $\mathrm{p}<0.05$; Figs. 3, 4). The root length of B. juncea in the control was around 7.5, 25 and $38.5 \mathrm{~mm}$ at the $2^{\text {nd }}, 4^{\text {th }}$ and $7^{\text {th }}$ day of experiment, respectively. The root length in the exposures at the consecutive times of record was from $2-3.5,13-16$ and $20-34 \mathrm{~mm}$, respectively. Also, the root length of $M$. sativa in the control was around 13, 24.5 and $32 \mathrm{~mm}$, while, in the exposures it was from $6-8.5,14.5$ -19 and $17-26.5 \mathrm{~mm}$, after 2, 4 and 7 days of

\section{Trang 38}


the test, respectively. In the control, the shoot length of B. juncea was around 2, 20 and $34 \mathrm{~mm}$ after 2, 4 and 7 days of incubation, respectively. However, in the toxin exposures, the shoot length was from $0.4-1.4,8-14$ and $20-27 \mathrm{~mm}$, respectively, after 2, 4 and 7 days of experiment. Similarly, the shoot length of $M$. sativa of the control was 8, 22 and $27 \mathrm{~mm}$ after 2, 4 and 7 days of incubation, respectively, whereas, it was from $4-7,12-17$ and $13-18 \mathrm{~mm}$ from the exposed $M$. sativa. In addition, high MC concentration from field water and cyanobacterial crude extract had stronger effect on the shoot development of $B$. juncea (Fig. 4a-c). In contrast, the development of root of $B$. juncea and the length of root and shoot of $M$. sativa were more or less similar between the high and low MC concentration exposures (Fig. 3 and 4d-f).

Inhibition on the root and shoot length of MC exposed seedlings in our study was consistent with previous records of McElhiney et al. [9] and Pflugmacher et al. [13]. Garbers et al. [4] indicated that MC regulated the phytohormone auxin, and MC are protein phosphatase inhibitors [8]. Therefore, exposure to MC would cause the disorder of cell development consequently inhibition of root and shoot growth of the exposed seedlings. Also, the water uptake reduction induced by $\mathrm{MC}$ as mentioned above would contribute to the decrease of shoot and root prolongation. Besides,
MC caused strong alteration of biotransformation and antioxidant enzyme activities in plants $[5,13$, 16] hence some energy was spent for the MC detoxification leading to the reduction of hydrocarbon and nutrient source for root and shoot development.

Summing up the adverse effects MC on plants, the seedlings exposed to MC would grow slower than those in control as observed in our experiments. Lastly, the response of $B$. juncea and $M$. sativa their shoot length to two different MC concentrations (20 and $200 \mu \mathrm{g} \mathrm{L}^{-1}$ ) could be species specific which need further investigation.

\section{CONCLUSIONS}

Microcystins concentration in water from Dau Tieng Reservoir was extremely high which possessed high risk to local residents who daily use water from the reservoir for their domestic activities. The MC from the water body caused severe impacts on germination of the seeds and inhibited the development of the seedlings during their early life stage including significant decrease of FW, root and shoot length. The results of this study confirmed the potent toxicity of cyanobacterial toxins from Dau Tieng Reservoir to plants.

Acknowledgements: This study was funded by the Vietnam National University - Hochiminh City under the project numbers B2012-24-01TÐ and A2013-48-01. 


\section{Sự nẩy mầm và phát triển của cây mầm Brassica juncea và Medicago sativa trong phơi nhiễm với nước nhiễm độc tố microcystins từ hồ Dầu Tiếng}

- Đào Thanh Sơn

Trường Đại học Bách Khoa TP. HCM

- Lê Thái Hằng

Trường Đại học Khoa học Tự nhiên TP. HCM

- Phạm Thanh Lưu

Đại học Tsukuba, Nhật Bản

- Đỗ Hồng Lan Chi

Đại học Quốc gia TP. HCM

\section{TÓM TÁ́T}

Sự hiện diện của vi khuẩn lam và độc tố của chúng là nguồn gốc của nhiều vấn đề nghiêm trọng đối với thực vật nước, động vật và con người trên thế giới. Tuy vậy, độc tính của độc tố vi khuẩn lam từ các thủy vực ở Việt Nam đối với sự nẩy mầm và phát triển của thực vật cho đến nay vẫn chưa được nghiên cứu. Trong nghiên cứu này, chúng tôi tìm hiểu ảnh hưởng của của microcystins (ở nồng độ 20 và $200 \mu g M C L-1)$ trong nước tự nhiên và dịch chiết của mẫu vi khuẩn lam tạo váng thu từ hồ Dầu Tiếng, lên sự nẩy mầm và phát triển của Brassica juncea và Medicago sativa trong suốt 7 ngày. Kết quả cho thấy rắng microcystins ức chế $10-35 \%$ sụ̣ nẩy mầm của hạt. Trọng lượng tươi của cây mầm $B$. juncea và $M$. sativa phơi nhiễm

với độc tố giảm lần lượt từ $44-89 \%$ và từ 55 - 90\%, so với cây mầm trong lô đối chứng. Chiều dài rễ mầm giảm đi $12-73 \%$ đối với $B$. juncea và giảm đi 17 - 54\% đối với M. sativa trong thời gian phơi nhiễm với độc tố MC. Tương tự, sự suy giảm chiều dài thân mầm cây phơi nhiễm, so với trong lô đối chứng, là từ $20-80 \%$ đối với cây mầm $B$. juncea và từ $13-52 \%$ đối $M$. sativa. Nhur vậy, việc sử dụng nước có nhiễm microcystins cho việc tưới tiêu có thể dẫn đến những ảnh hưởng xấu lên chất lượng và mùa vụ cây trồng. Chúng tôi suy luận rằng hấp thu microcystins vào hạt phơ nhiễm có thể được chuyển đến người tiêu thụ thông qua chuỗi thức ăn.

Từ khóa: Brassica juncea, Medicago sativa, sự phát triển, microcystins, cây mầm. 


\section{REFERENCES}

[थ]. Chen J., Song L., Dai J., Liu Z., Effects of microcystins on the growth and the activity of superoxide dismutase and peroxidase of rape (Brassica napus L.) and rice (Oryza sativa L.). Toxicon 43: 393-400 (2004).

[2] Codd G.A., Cyanobacterial toxins: their occurrence in aquatic environments and significance to health, Bulletin de l'Institut océanographique Monaco, 19: 483-500 (1999).

[3] Dao T. S., Pham T. L., Do-Hong L. C., Bui B. T., Occurrence of toxic cyanobacteria and their toxins from freshwater bodies in Vietnam - a short review, J. Sci. Tech. 50 (1C): 264-269 (2012).

[4] Garbers C., DeLong A., Deruere J., Bernasconi P., Soll D., A mutation in protein phosphatase $2 \mathrm{~A}$ regulatory subumit $\mathrm{A}$ affects auxin transport in Arabidopsis, The EMBO. 15: 2115-2124 (1996).

[5] Ha M.H., Pflugmacher S., Phytotoxic effects of the cyanobacterial neurotoxin anatoxin-a: morphological, physiological and biochemical responses in aquatic macrophyte, Ceratophyllum demersum. Toxicon 70: 1-8 (2013).

[6] Jarvenpaa S., Lundberg-Niinisto C., Spoof L., Sjovall O., Tyystjarvi E., Meriluoto J., Effects of microcystins on broccoli and mustard, and analysis of accumulated toxin by liquid chromatography-mass spectrometry, Toxicon 49: 865-874 (2007).

[7] Kurki-Helasmo K., Meriluoto J., Microcystin uptake inhibits growth and protein phosphatase activity in mustard (Sinapis alba L.) seedlings, Toxicon 36: 1921-1926 (1998).

[8] MacKintosh C., Beattie K. A., Klumpp S., Cohen P., Codd G.A., Cyanobacterial
microcystin-LR is a potent and specific inhibitor of protein phosphatases 1 and $2 \mathrm{~A}$ from both mammals and higher plants, FEBS Letters. 264: 187-192 (1990).

[9] McElhiney J., Lawton L. A., Leifert C., Investigations into the inhibitory effects of microcystins on plant growth, and the toxicity of plant tissues following exposure, Toxicon 39: 1411-1420 (2001).

[10] Mikhailov A., Harmala-Brasken A. S., Herman J., Meriluoto J., Eriksson J. E., Identification of ATP-synthetase as a novel intracellular target for microcystin-LR, Chem. Biol. Interact. 142: 223-237 (2003).

[11] Mitrovic S. M., Allis O., Furey A., James K. J., Bioaccumulation and harmful effects of microcystin-LR in the aquatic plants Lemna minor and Wolffia arrhiza and the filamentous alga Chladophora fracta, Exotoxicol. Environ. Saf. 61: 345-352 (2005).

[12] Pflugmacher S., Wiegand C., Beattie K. A., Krause E., Steinberg C. E. W., Codd G. A., Uptake, effects and metabolism of cyanobacterial toxins in the emergent reed plant Phragmites australis (Cav.) Trin. ex Steud. Environ. Toxicol. Chem. 20: 846-852 (2001).

[13] Pflugmacher S., Aulhorn M., Grimm B., Influence of a cyanobacterial crude extract containing microcystin-LR on the physiology and antioxidative defence systems of different spinach variants. New Phycol. 175: 482-489 (2007).

[14] Pietsch C., Wiegand C., Ame M.V., Nicklisch A., Wunderlin D., Pflugmacher S., The effects of cyanobacterial crude extract on different aquatic organisms: Evidence for 
cyanobacterial toxin modulating factors. Environ. Toxicol. 16: 535-542 (2001).

[15] Sivonen K., and Jones G., Cyanobacterial toxins. In: Chorus, I., Bartram, J. (Eds) Toxic Cyanobacteria in Water - a guide to their public health consequences, monitoring and management, $E \& F N$ Spon, London, pp. 41-111 (1999).

[16] Stuven J., Pflugmacher S., Antioxidative stress response of Lepidium sativum due to exposure to cyanobacterial secondary metabolites, Toxicon 50: 85-93 (2007).

[17] Yin L., Huang J., Huang W., Li D., Liu Y., Responses of antioxidant system in Arabidopsis thaliana suspension cells to the toxicity of Microcystin-RR, Toxicon 46: 859-864 (2005).
[18] Yin L., Huang J., Huang W., Li D., Wang G., Liu Y., Microcystin-RR-induced accumulation of reactive oxygen species and alteration of antioxidant systems in tobaco BY-2 cells. Toxicon 46: 507-512 (2005).

[19] Weiss J., Liebert H. P., Braune W., Influence on microcystin-RR on growth and photosynthetic capacity of the duckweed Lemma minor L. J. Appl. Bot. 74: 10-105 (2000).

[20] Wiegand C., Peuthert A., Pflugmacher S., Carmeli S., Effects of Microcin SF608 and microcystin-LR, two cyanobacterial compounds produced by Microcystis sp., on aquatic organisms, Environ Toxicol, 17: 400406 (2002). 